\begin{tabular}{|l|l|l||}
\hline \multicolumn{2}{|c|}{ PublisherInfo } \\
\hline \hline PublisherName & $:$ & BioMed Central \\
\hline \hline PublisherLocation & $:$ & London \\
\hline \hline PublisherImprintName & $:$ & BioMed Central \\
\hline \hline
\end{tabular}

\title{
Screening with X-rays
}

\begin{tabular}{|l|l|l||}
\hline \multicolumn{2}{|c|}{ ArticleInfo } \\
\hline \hline ArticleID & $:$ & 3793 \\
\hline \hline ArticleDOI & $:$ & $10.1186 /$ gb-spotlight-20001010-01 \\
\hline \hline ArticleCitationID & $:$ & spotlight-20001010-01 \\
\hline \hline ArticleSequenceNumber & $:$ & 230 \\
\hline \hline ArticleCategory & $:$ & Research news \\
\hline \hline ArticleFirstPage & $:$ & 1 \\
\hline \hline ArticleLastPage & $:$ & 2 \\
\hline \hline & & RegistrationDate : 2000-10-10 \\
ArticleHistory & $:$ & OnlineDate \\
\hline \hline ArticleCopyright & $:$ & BioMed Central Ltd2000-10-10 \\
\hline \hline ArticleGrants & $:$ & \\
\hline \hline ArticleContext & $:$ & 130591111 \\
\hline \hline
\end{tabular}




\section{William Wells}

Email: wells@biotext.com

In the October Nature Biotechnology, Nienaber et al. demonstrate that drug or inhibitor leads can be identified by high throughput X-ray crystallography (Nat. Biotech. 2000, 18:1105-1108). Pre-formed protein crystals are soaked in solvents containing mixtures of 100 compounds before the crystals are examined by X-ray crystallography. Nienaber et al. look for changes in the electron-density map caused by ligand binding. The compounds in each mixture are chosen to be diverse in shape so that they can be differentiated readily, and the technique allows the site and orientation of binding to be identified. Nienaber $e t$ al. use this method to screen thousands of compounds per day in a successful search for a high affinity inhibitor of the anti-cancer target urokinase.

\section{References}

1. Nature Biotechnology, [http://www.nature.com/nbt/] 